Article

\title{
The Immunogenicity of Branded and Biosimilar Infliximab in Rheumatoid Arthritis According to Th9-Related Responses
}

\author{
Rossella Talotta ${ }^{1, *,+}$, Angela Berzi ${ }^{2,+}$, Andrea Doria $^{3}$, Alberto Batticciotto ${ }^{1}$, Maria Chiara Ditto ${ }^{1}$, \\ Fabiola Atzeni ${ }^{1}$, Piercarlo Sarzi-Puttini ${ }^{1}$ and Daria Trabattoni ${ }^{2}$ \\ 1 Department of Rheumatology, Azienda Ospedaliera-Polo Universitario Luigi Sacco, Milan 20157, Italy; \\ alberto.batticciotto@hsacco.it (A.B.); mariachiara.ditto@hsacco.it (M.C.D.); atzenifabiola@gmail.com (F.A.); \\ sarzi@tiscali.it (P.S.-P.) \\ 2 Department of Biomedical and Clinical Sciences, Azienda Ospedaliera-Polo Universitario Luigi Sacco, \\ Milan 20157, Italy; angyberzi@gmail.com (A.B.); daria.trabattoni@unimi.it (D.T.) \\ 3 Department of Rheumatology, University of Padua, Padua 35100, Italy; adoria@unipd.it \\ * Correspondence: rossella.talotta@asst-fbf-sacco.it; Tel.: +39-023-9042906; Fax +39-023-9042941 \\ + These authors contributed equally to this work.
}

Received: 15 September 2017; Accepted: 6 October 2017; Published: 12 October 2017

\begin{abstract}
Our objective was to evaluate the immunogenicity of branded and biosimilar infliximab by detecting changes in T-helper-9 (Th9) percentages induced by an in vitro stimulation test. Methods: Peripheral blood mononuclear cells collected from 55 consecutive rheumatoid arthritis (RA) outpatients (15 drug free, 20 successfully treated with branded infliximab, 20 branded infliximab inadequate responders) and 10 healthy controls were cultured, with or without $50 \mu \mathrm{g} / \mathrm{mL}$ of infliximab originator (Remicade ${ }^{\circledR}$ ) or $50 \mu \mathrm{g} / \mathrm{mL}$ of infliximab biosimilar (Remsima ${ }^{\circledR}$ ) for $18 \mathrm{~h}$. Th9 lymphocytes were identified by means of flow cytometry as PU.1 and IRF4-expressing, IL-9-secreting $\mathrm{CD}^{+} \mathrm{T}$ cells. Furthermore, the markers CCR7 and CD45RA were used to distinguish naïve from memory IL-9 producer cells. Results: Under unstimulated conditions, the drug-free RA patients had the highest percentages of Th9 lymphocytes. Following stimulation with branded infliximab, the percentages of PU.1 and IRF4-expressing Th9 cells, CCR7 ${ }^{+}, \mathrm{CD}_{4} 5 \mathrm{RA}^{-}$ (central memory) and $\mathrm{CCR}^{-}, \mathrm{CD}^{2} 5 \mathrm{RA}^{-}$(effector memory) cells significantly increased in the group of inadequate responders, but no significant variation was observed after exposure to the biosimilar of infliximab. Conclusions: Th9 cells seem to be involved in the immune response to the epitopes of branded, but not biosimilar, infliximab, and this may depend on the recall and stimulation of both central and effector memory cells.
\end{abstract}

Keywords: biosimilars; Th9 lymphocytes; rheumatoid arthritis; infliximab

\section{Introduction}

Rheumatoid arthritis (RA) is an autoimmune chronic disease characterized by inflammation of peripheral joints, with a varying degree of systemic involvement. The pathogenesis is partly understood and relies on the activation of cells belonging either to innate and adaptive immunity, with the subsequent production of cytokines and chemokines contributing to final synovitis and systemic inflammation. The treatment of RA has been remarkably implemented in recent decades. Several conventional and biological drugs have been developed in order to counteract the activation of the immune system by acting at different steps of the inflammatory cascade. Particularly, biological agents currently approved for RA include: anti-Tumor Necrosis Factor- $\alpha$ (TNF) drugs (infliximab, etanercept, adalimumab, certolizumab pegol, golimumab), an anti-CD20 drug (rituximab), a receptor 
antagonist of interleukin-1 (anakinra), an antagonist of the receptor of interleukin-6 (tocilizumab) and a fusion protein containing the Cytotoxic T Lymphocyte Antigen-4 domain activity (abatacept). All these drugs are characterized by high specificity that allows the recognition of a specific molecule, thus preventing further repercussions on other cells or organs. In addition, biosimilar drugs of infliximab, etanercept and rituximab have been recently commercialised, and their use has been spread due to their non-negligible cost-sparing effects and comparable profiles, in terms of efficacy and safety, with the reference products.

The use of biological drugs to treat RA has led to considerable improvements in inflammation control and the prevention of structural damage. However, there are patients who develop adverse events or experience the progressive loss of treatment efficacy. The unsuccessful outcome of biological therapy may be due to immunogenicity (i.e., the capacity of a drug to induce an immune-mediated response against its own epitopes), which may depend on a number of drug- and patient-related factors. Biological monoclonal antibodies (MoAbs) are synthesised in murine cells and contain some foreign amino acid sequences that are potentially highly antigenic. The $25 \%$ murine structure of infliximab and its biosimilar compounds make them more immunogenic than other anti-rheumatic biological agents, despite comparable immunogenicity profiles, as assessed by the production of anti-drug antibodies (ADAs) between originators and biosimilars.

RA is characterized by an aberrant activation of adaptive immunity that is mirrored by the interplay of many sub-sets of T helper (Th) lymphocytes. In an altered cytokine background, such as that of RA patients, the administration of biological drugs that are potentially highly antigenic may induce the aberrant activation of specific $\mathrm{T}$ and $\mathrm{B}$ effector responses against drug epitopes. There is considerable evidence that the production of ADAs mainly depends on the activation of a Th2 cell pathway; however, as suggested by a few reports, the paradoxical activation of Th1 and Th17 responses following the administration of infliximab may also occur in non-responding RA patients.

The levels of Th9 cells, which are specialised for producing IL-9, but can also produce IL-10, IL-17, IL-21 and IL-22, are increased in the bloodstream and synovial membranes of RA patients, where they are directly related to the degree of lymphoid organisation and the production of autoantibodies, such as anti-citrullinated peptide antibodies (ACPAs). However, no study has yet investigated the role of Th9 lymphocytes in the immunogenicity of biological agents by comparing originator and biosimilar compounds.

The aim of this study was to evaluate if Th-9 cells can mediate drug immunogenicity and to compare the Th9-related immunogenicity of the infliximab originator (Remicade ${ }^{\circledR}$ ) and its biosimilar compound $\left(\right.$ Remsima $\left.^{\circledR}\right)$ in a cohort of infliximab-responder and inadequate responder (IR) RA patients by means of an in vitro stimulation assay, taking into account the demographic and clinimetric features of the patients, the use of concomitant drugs, and the reason for discontinuing infliximab.

\section{Results}

\subsection{Baseline Demographic and Clinical Assessment}

At the time of enrolment, five of the 15 drug-naïve RA patients (14 Caucasians and one Chinese; 12 females; mean age $54.8 \pm 16.2$ years; mean disease duration $2.3 \pm 3.9$ years) had ACPAs, seven had rheumatoid factor (RF), and two had anti-nuclear antibodies (ANAs); their mean C-reactive protein/28-joint disease activity score (CRP-DAS28) was $4.6 \pm 1.0$. All were taking anti-inflammatory and analgesic drugs as needed.

Fifteen of the 20 good responders to infliximab (19 Caucasians and one Hispanic; 16 females, mean age $61.3 \pm 12.2$ years; mean disease duration $13.4 \pm 7.2$ years) had ACPAs, 12 had ANAs, 11 had RF, three had anti-double stranded DNA antibodies (anti-dsDNA), one had anticardiolipin antibodies (ACLAs), and one had anti-extractable nuclear antigen antibodies (ENAs). Their RA had been well controlled by infliximab (Remicade ${ }^{\circledR}$ ) for a mean of $8.3 \pm 3.9$ years (mean CRP-DAS28 at the time of 
blood sampling $2.5 \pm 1.0)$. The concomitant medications were prednisone (2.5-10 mg/day) in eight patients, methotrexate (5-15 mg/week) in 20, and hydroxychloroquine (200-400 mg/day) in three.

Seventeen of the 20 non-responders to infliximab (19 Caucasians and one Indian; 15 females; mean age $57.0 \pm 12.2$ years; mean disease duration $18.1 \pm 9.5$ years) had ANAs, 15 had ACPAs, 15 had RF, three had ACLAs, two had anti-dsDNA, and two had anti-ENAs. Thirteen were being treated with intravenous (i.v.) abatacept $(10 \mathrm{mg} / \mathrm{kg}$ every four weeks), five were being treated with i.v. tocilizumab $(8 \mathrm{mg} / \mathrm{kg}$ every four weeks), one was being treated with subcutaneous (s.c.) etanercept (50 mg once a week), and one was being treated with s.c. certolizumab pegol (200 mg every other week); these treatments were the second (8 patients), third (8 patients) or fourth biological line (4 patients). The patients had been treated with infliximab (Remicade ${ }^{\circledR}$ ) for a mean of $2.4 \pm 1.9$ years, and had discontinued the drug for a mean of $8.0 \pm 2.5$ years due to inefficacy (11 cases) or adverse events (mainly allergic or infusion reactions, 9 cases). Their concomitant conventional drugs were prednisone (2.5-10 mg/day) in 14 cases, methotrexate (5-15 mg/week) in nine cases and hydroxychloroquine (200-400 mg/day) in five cases. Their mean CRP-DAS28 was $2.9 \pm 0.8$ at the time of blood sampling. Demographic and clinical characteristics are displayed in Table 1.

Treated patients and untreated patients were matched for gender and age, and significantly differed for disease duration ( $p<0.001$, Student's $t$ Test for unpaired samples); ANAs and ACPAs were more frequently detected in longstanding RA treated patients than in untreated ones $(p<0.001$ and $p=0.006$, respectively; Pearson's Chi squared test).

Good responders and non-responders to infliximab were matched for gender, age, disease duration, autoantibody subsets (Student's $t$ Test for unpaired samples and Pearson's Chi squared test); whereas they significantly differed for methotrexate and prednisone medium dose intake, (respectively $p=0.003$ and 0.030; Student's $t$ Test for unpaired samples).

Table 1. Demographic characteristics of the population included in the study. RA: rheumatoid arthritis; IFX: infliximab; SD: standard deviation; F: females; M: males; ACPAs: anti-citrullinated-protein antibodies; RF: rheumatoid factor; ANAs: anti-nuclear antibodies; anti-dsDNA: anti-double stranded DNA antibodies; anti-ENAs: anti-extractable nuclear antigen antibodies; ACLAs: anticardiolipin antibodies; LAC: lupus anticoagulant; CRP-DAS28: C-reactive protein/28-joint disease activity score; NSAIDs: non-steroidal anti-inflammatory drugs.

\begin{tabular}{|c|c|c|c|c|}
\hline Variables & Healthy Controls & $\begin{array}{l}\text { Treatment-Naïve } \\
\text { RA Patients }\end{array}$ & $\begin{array}{c}\text { RA Patients } \\
\text { Responding to IFX }\end{array}$ & $\begin{array}{c}\text { RA Patients } \\
\text { Non-Responding to IFX }\end{array}$ \\
\hline Number of subjects & 10 & 15 & 20 & 20 \\
\hline Mean age $\pm S D$, years & $43.9 \pm 8.3$ & $54.8 \pm 16.2$ & $61.3 \pm 12.2$ & $57.0 \pm 12.2$ \\
\hline Mean disease duration $\pm S D$, years & / & $2.3 \pm 3.9$ & $13.4 \pm 7.2$ & $18.1 \pm 9.5$ \\
\hline Gender, F/M (number) & $4 / 6$ & $12 / 3$ & $16 / 4$ & $15 / 5$ \\
\hline ACPAs+, (number) & / & 5 & 15 & 15 \\
\hline$R F+$, (number) & / & 7 & 11 & 15 \\
\hline ANAs+, (number) & / & 2 & 12 & 17 \\
\hline Anti-dsDNA Ab, (number) & / & 0 & 3 & 2 \\
\hline Anti-ENAs $\mathrm{Ab}+$, (number) & / & 0 & 1 & 3 \\
\hline ACLAs/LAC+, (number) & / & 0 & 1 & 2 \\
\hline Mean CRP-DAS28 \pm SD & / & $4.6 \pm 1.0$ & $2.5 \pm 1.0$ & $2.9 \pm 0.8$ \\
\hline Prednisone (2.5-10 mg/day), (number) & / & / & 8 & 14 \\
\hline Methotrexate (5-15 mg/week), (number) & / & / & 20 & 9 \\
\hline Hydroxychloroquine (200-400 mg/day), (number) & / & / & 3 & 5 \\
\hline NSAIDs, (number) & / & 14 & as needed & as needed \\
\hline
\end{tabular}

\subsection{Thelper 9 Cells at Baseline}

The baseline percentage of PU.1 $1^{+}$, IRF4 $4^{+}$Th9 cells was higher in the drug-naïve patients than in the healthy controls and treated patients $(p<0.01)$ (Figure 1). There was no significant difference in the percentage of OX40-expressing, IL-9-producing, $\mathrm{CD}^{+} \mathrm{T}$ cells between the healthy controls and any of the patient groups (Figure 2), possibly because of the involvement of different pathways in the differentiation of Th9 cells [1]; however, the percentage of OX40-expressing CD4 ${ }^{+} \mathrm{T}$ cells was higher in the patient groups than in the controls. The greater frequency of Th9 cells among the RA patients was not associated with higher ANA or other autoantibody levels, disease duration, baseline 
CRP-DAS28, nor was it associated with the reason for discontinuing infliximab or the number of previous biological drugs administered to the non-responders. Moreover, a multivariate analysis did not reveal any significant influence of concomitant conventional or biological treatments, although the heterogeneity of the biological therapies and the limited number of cases may have biased the statistical evaluation.

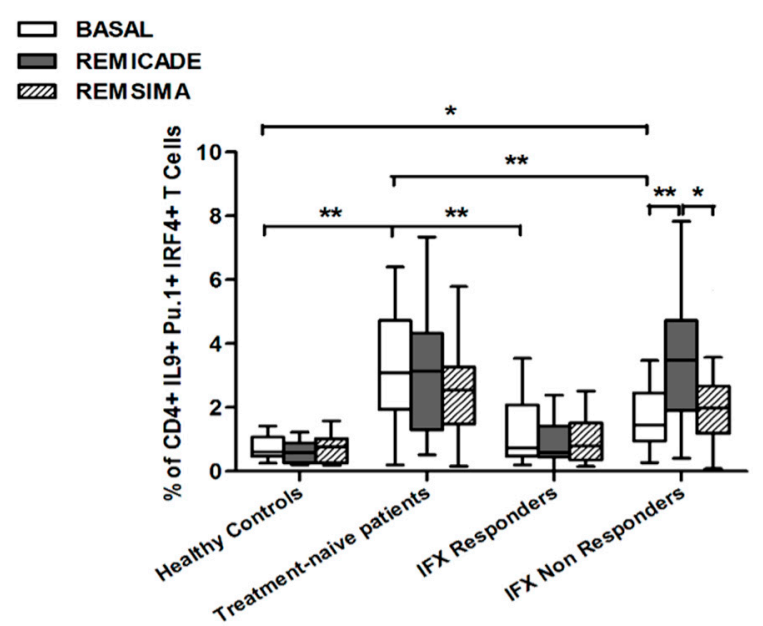

Figure 1. Percentages of PU. $1^{+}, \mathrm{IRF} 4^{+}, \mathrm{IL}-9^{+} \mathrm{CD} 4^{+} \mathrm{T}$ cells at baseline and after exposure to branded and biosimilar infliximab. ${ }^{*} p<0.05,{ }^{* *} p<0.01$.

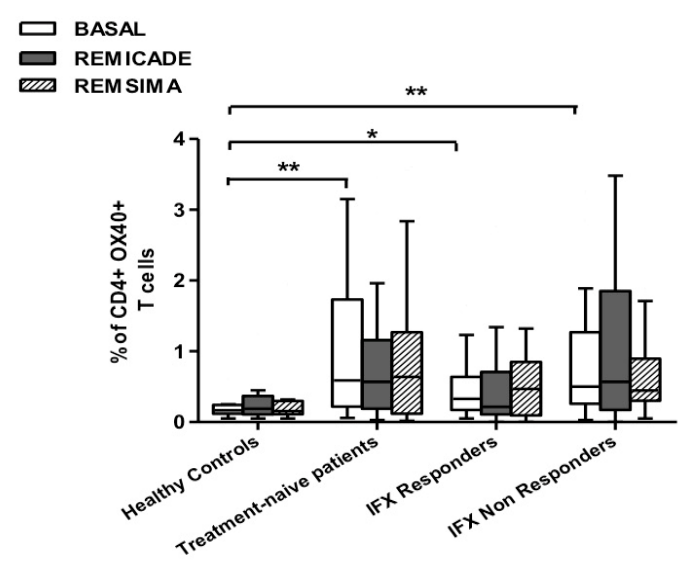

Figure 2. Percentages of $\mathrm{OX} 40^{+}, \mathrm{IL}-9^{+} \mathrm{CD} 4^{+} \mathrm{T}$ cells at baseline and after exposure to branded and biosimilar infliximab. ${ }^{*} p<0.05,{ }^{* *} p<0.01$.

In brief, at baseline the difference in the percentage of Th9 cells between the healthy controls and the RA patients was observed in the group of untreated patients. This finding indicates that the activation of Th9 cells is a distinctive characteristic of RA and can be restored by concomitant efficacious conventional or biological treatments.

\subsection{Effects of Infliximab (Remicade ${ }^{\circledR}$ ) on T Helper 9 Cells}

Stimulation with branded infliximab increased the percentage of PU. $1^{+}$and IRF4 $4^{+}$Th9 cells only in the IR group of patients (Figure 1). There were no differences in OX40-expressing, IL-9-producing $\mathrm{CD}^{+} \mathrm{T}$ cells or OX40-expressing $\mathrm{CD} 4^{+} \mathrm{T}$ cells, before and after infliximab exposure (Figure 2), possibly because of the widespread expression of OX40 in the Th cell pool [2].

We also investigated whether Th9 lymphocytes may be activated by means of a specific stimulus on Th memory cells from patients who had discontinued infliximab because of inefficacy or adverse events. Antigen stimulation can induce central memory $\left(\mathrm{CCR} 7^{+}, \mathrm{CD} 5 \mathrm{RA}^{-}\right) \mathrm{T}$ cells to migrate from 
lymph nodes to peripheral tissues, lose CCR7, and differentiate into $\left(\mathrm{CCR}^{-}{ }^{-}, \mathrm{CD}^{2} 5 \mathrm{RA}^{-}\right)$effector memory $\mathrm{T}$ cells with immediate activation. Furthermore, in the case of protracted low-dose antigen stimulation, they may be able to re-express the molecule CD45RA (terminally differentiated effector memory, TEMRA) and acquire surveillance functions with less pronounced effector properties $[3,4]$. We therefore subdivided IL-9-secreting $\mathrm{CD}^{+} \mathrm{T}$ cells on the basis of the expression of CCR7 and CD45RA, which makes it possible to distinguish among naïve, central memory, effector memory and TEMRA cells. All of these cell pools were increased in the untreated RA patients in comparison with the other groups. Following the addition of infliximab, IL- $9^{+}, \mathrm{CCR} 7^{+}, \mathrm{CD} 45 \mathrm{RA}^{-}$central memory cells and IL- $9^{+}, \mathrm{CCR}^{-}{ }^{-}, \mathrm{CD}^{2} 5 \mathrm{RA}^{-}$effector memory cells (but not naïve Th9 cells) were increased in the infliximab IR group, thus indicating that these cell pools may account for the change in the percentage in PU.1 and IRF4-expressing, IL-9-secreting CD4 ${ }^{+} \mathrm{T}$ cells (Figures 3-5). On the contrary, the percentage of TEMRA lymphocytes did not vary, presumably because of the limited proliferative activity of this cell pool (Figure 6).

The gating strategy for the identification of naïve, central memory, effector memory and TEMRA $\mathrm{CD}^{+} \mathrm{T}$ lymphocytes is shown in Figure 7.

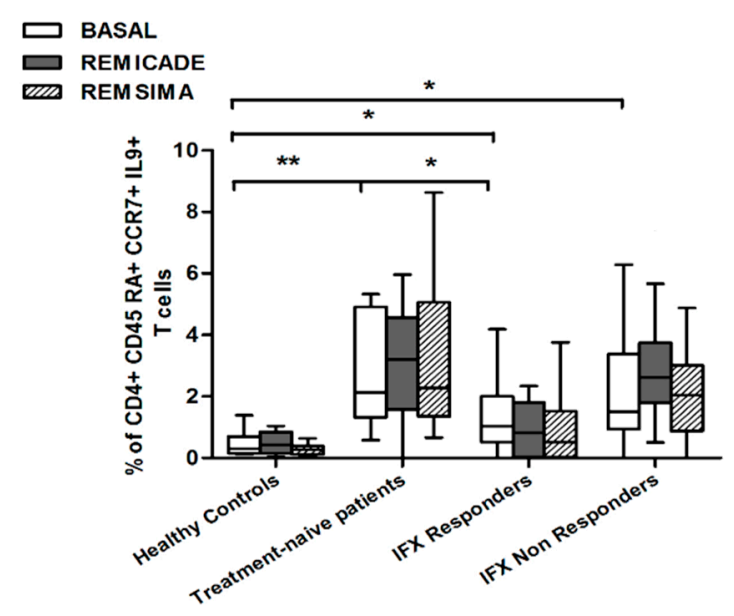

Figure 3. Percentages of $\mathrm{CD} 45 \mathrm{RA}^{+}, \mathrm{CCR} 7^{+}, \mathrm{IL}-9^{+} \mathrm{CD} 4^{+}$(naïve) $\mathrm{T}$ cells at baseline and after exposure to branded and biosimilar infliximab. ${ }^{*} p<0.05,{ }^{* *} p<0.01$.

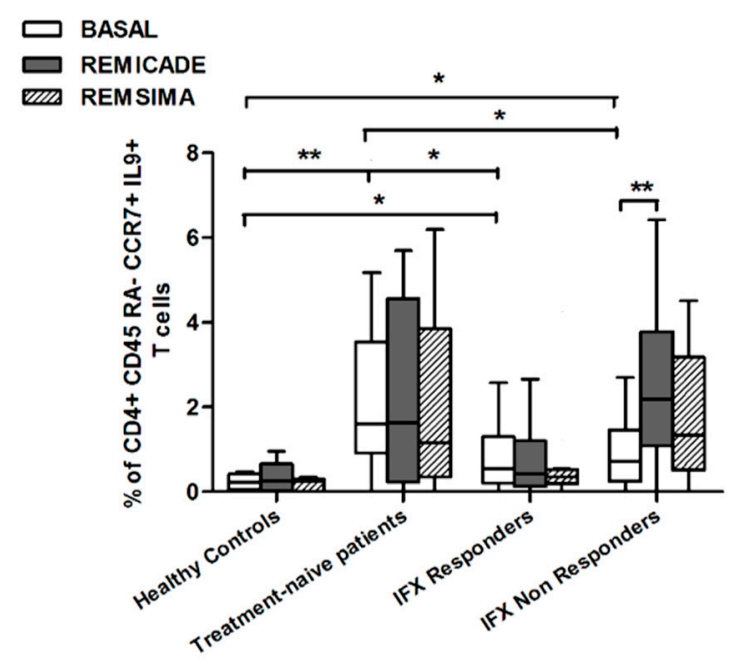

Figure 4. Percentages of CD45RA ${ }^{-}, \mathrm{CCR}^{+}, \mathrm{IL}-9^{+} \mathrm{CD} 4^{+}$(central memory) T cells at baseline and after exposure to branded and biosimilar infliximab. ${ }^{*} p<0.05,{ }^{* *} p<0.01$. 


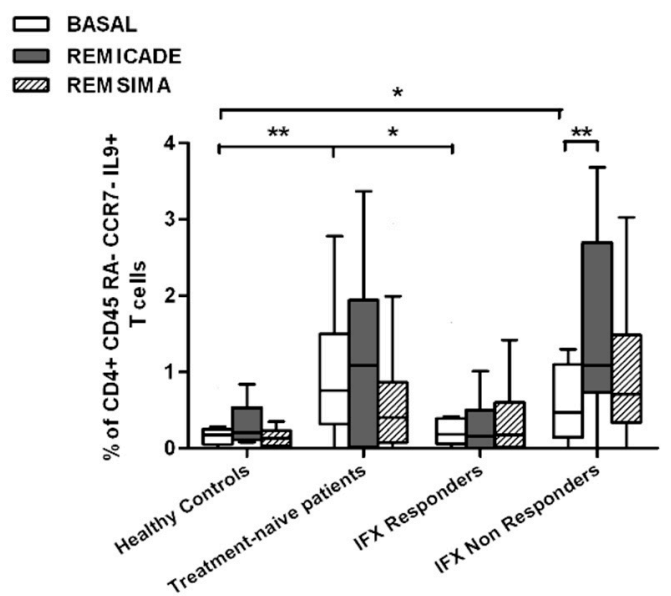

Figure 5. Percentages of $\mathrm{CD}^{2} 5 \mathrm{RA}^{-}, \mathrm{CCR}^{-}, \mathrm{IL}^{-} 9^{+} \mathrm{CD} 4^{+}$(effector memory) $\mathrm{T}$ cells at baseline and after exposure to branded and biosimilar infliximab. ${ }^{*} p<0.05,{ }^{* *} p<0.01$.

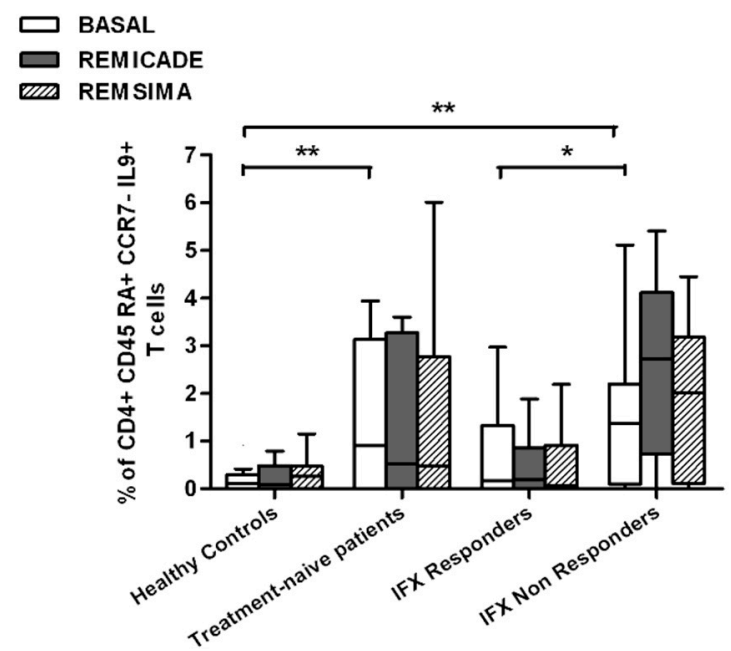

Figure 6. Percentages of CD45RA ${ }^{+}, \mathrm{CCR}^{-}, \mathrm{IL}^{-} 9^{+} \mathrm{CD}^{+}$(terminally differentiated effector memory, TEMRA) T cells at baseline and after exposure to branded and biosimilar infliximab. ${ }^{*} p<0.05,{ }^{* *} p<0.01$.
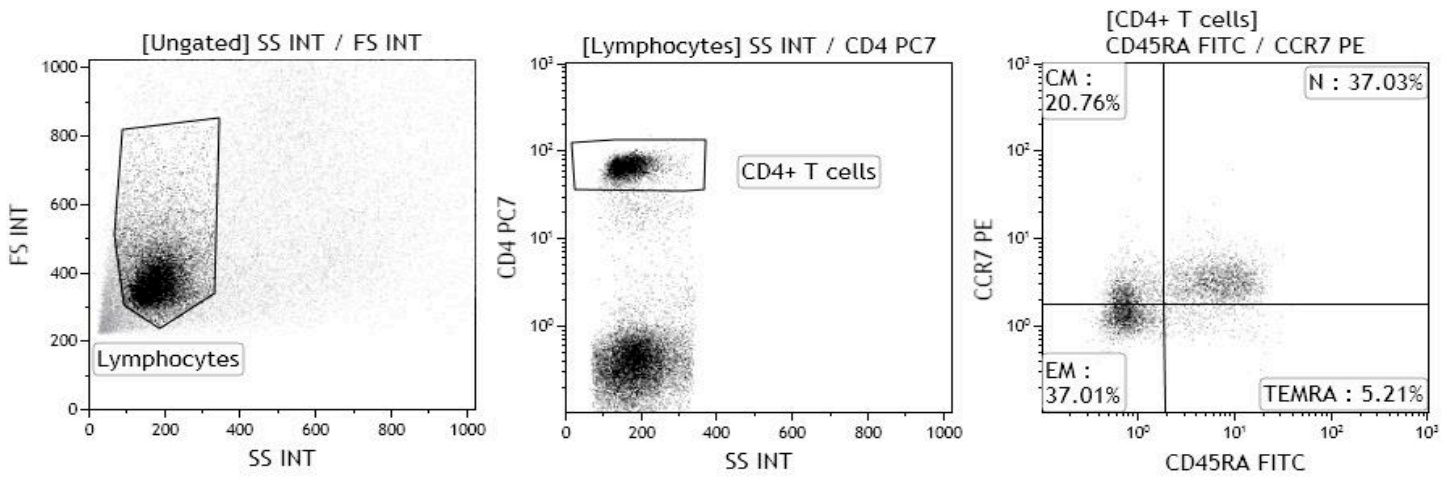

Figure 7. Gating strategy for the identification of naïve $\mathrm{CD} 4^{+} \mathrm{T}$ lymphocytes $(\mathrm{N})$, central memory $\mathrm{CD} 4^{+}$ $\mathrm{T}$ lymphocytes (CM), effector memory $\mathrm{CD}^{+} \mathrm{T}$ lymphocytes (EM) and terminally differentiated effector memory (TEMRA) CD4 ${ }^{+} \mathrm{T}$ lymphocytes. The lymphocyte population was gated on forward and side scatter properties, and further gated for CD4, CCR7, CD45RA expression; at least 20,000 events were acquired within the CD4 gate. The samples were acquired using a Gallios flow cytometer, and the data were analysed using Kaluza software (both Beckman Coulter). 


\subsection{Comparison of the Effects of Remicade ${ }^{\circledR}$ and Remsima ${ }^{\circledR}$ on T Helper 9 Cells}

We repeated the previous experiment using the biosimilar compound CT-P13 (Remsima ${ }^{\circledR}$ ). As in the experiment with the original infliximab, there were no significant variations in the percentages of PU. $1^{+}, \mathrm{IRF}^{+}$Th9 cells, under basal or stimulated conditions, in the healthy controls and the untreated or responding RA patients, but the addition of the biosimilar did not significantly increase the percentage of PU.1 and IRF4-expressing, IL-9-secreting CD4 ${ }^{+} \mathrm{T}$ cells or IL-9-secreting central and effector memory $\mathrm{CD}^{+} \mathrm{T}$ cells in the infliximab IR group, as was observed after the addition of branded infliximab (Figures 1, 4 and 5). Furthermore, as in the case of branded infliximab, exposure to biosimilar CT-P13 did not induce a significant change in the percentages of IL-9-secreting naïve and TEMRA CD4 $4^{+} \mathrm{T}$ lymphocytes (Figures 3 and 6), OX40-expressing, IL-9-producing $\mathrm{CD} 4^{+} \mathrm{T}$ cells or OX40-expressing $\mathrm{CD}^{+} \mathrm{T}$ cells in any of the patient groups (Figure 2).

\section{Discussion}

The aims of this study were to investigate the possible relationship between Th9 cells and the outcome of infliximab biological therapy, and to demonstrate that the immunogenic profiles of branded and biosimilar infliximab are comparable in terms of Th9-driven immune responses. The immunogenicity of a drug depends on the presence of the specific $B$ and $T$ epitopes contained in the primary amino acid sequence, or developing during post-translational modifications [5-7]. The most widely accepted hypothesis is that the production of ADAs is the mechanism underlying a drug-induced immune response [8-12], although it may also be responsible for the development of adverse events or a progressive loss of efficacy. The immunogenicity of biological drugs (especially chimeric molecules such as infliximab) may be partly due to the induction of ADAs, but we and other authors have shown that other immune pathways, such as the antigen-specific activation of Th1 or Th17 cells may be an alternative explanation for the rejection of biological treatments $[13,14]$. Th9 cells are a sub-set of $\mathrm{T}$ helper cells that develop from naïve or primed Th2 lymphocytes in the presence of IL-4 and TGF $\beta$, and are characterised by transcriptional factors-PU-1 and IRF4. Furthermore, co-stimulatory molecules (including OX40 and Notch) and other cytokines (such as IL-1 $\beta$, IL-25, IL-33, type I interferons, and thymic stromal lymphopoietin) are involved in promoting Th9 differentiation and IL-9 production [1]. These cells represent the main source of IL-9, although other cells such as Th2, Th17 and Treg cells may also make a contribution $[15,16]$. IL-9 is capable of activating various cells, including Th17 and Treg lymphocytes [17], and therefore, depending on the local microenvironment, Th9 lymphocytes may direct the immune response towards autoimmunity/inflammation or tolerance. IL-9 and Th9 cells are increased in subjects with inflammatory arthritis, connective tissue diseases, autoimmune colitis, and autoimmune encephalomyelitis [18-24]. In a previous experiment, we found an increased prevalence of IFN $\gamma$-, IL-4-, IL-17-, IL-9-secreting CD4 ${ }^{+}$T cells in RA patients, although there was no significant association with therapeutic outcomes [25]; this unusual behaviour may be related to the heterogeneity and plasticity of IL-9-producing $\mathrm{CD} 4^{+} \mathrm{T}$ cells, which may also include regulatory cells [26].

In line with these data, our results showed a higher percentage of Th9 cells in the peripheral blood of RA patients than in that of healthy controls; the levels were particularly high in untreated patients, whereas treatment with conventional or biological drugs seemed to reduce the difference. Following stimulation with original infliximab, the percentage of PU. $1^{+}, \mathrm{IRF} 4^{+}$Th9 cells increased in the infliximab IR group and this finding was confirmed when the experiment was repeated with central and effector memory IL- $9^{+}, \mathrm{CD} 4^{+} \mathrm{T}$ cells, but not with naïve or TEMRA IL-9 producer $\mathrm{CD} 4^{+}$ T cells.

$\mathrm{PU}^{+}, \mathrm{IRF}^{+}$Th9 cells may increase following antigenic stimulation with infliximab in patients who have discontinued treatment, possibly because of the recall and activation of central and effector memory Th9 cells, but when we assessed the response of PU.1 and IRF4-expressing, IL-9-secreting CD4 ${ }^{+}$ $\mathrm{T}$ lymphocytes to biosimilar infliximab, we did not find any significant variation from baseline in any of the four groups, although there was a trend in the case of central and effector memory cells. A possible 
inhibitory effect on memory Th cells related to IL-10, produced in vitro upon reverse signaling on mTNF- $\alpha$-bearing dendritic cells (DCs), or by memory T cells producing IL-10—particularly expanded in tolerant patients-cannot be excluded. Effector memory Th cells were reported to be consistently blocked by the IL-10, induced in vitro by the drug in tolerant patients and, to a lesser extent, in patients who interrupted therapy [27]. In our previous study [13], we reported an increase in the percentage of Treg cells in IFX-responders, compared to IFX naïve and IFX non-responders, even though we did not detected differences in the frequency of IL-10-producing Tregs among the groups of patients.

The discrepancy between branded and biosimilar infliximab may be due to various reasons. There was a trend towards an increase in the overall percentage of central and effector memory Th9 lymphocytes after exposure to biosimilar infliximab, but the difference was not significant, possibly because of the small number of patients. Furthermore, our experiments were carried using single batches of Remicade ${ }^{\circledR}$ and Remsima ${ }^{\circledR}$, but it is known that there may be structural differences between one batch and another of the same drug. The epitopes recognised by Th9 cells upon exposure to branded infliximab may not be the same as those recognised upon exposure to the biosimilar, due to differences in charge, amount of aggregates and unassembled forms, and post-translational motifs such as the pattern of glycosylation $[28,29]$. The greater fucosylation in the crystallisable fragment $(\mathrm{Fc})$ of biosimilar infliximab may prevent interaction with the Fc $\gamma$ R (especially FC $\gamma$ RIIIa and FC $\gamma$ RIIIb) of mononuclear cells $[30,31]$. This has been related to reduced antibody-dependent cell cytotoxicity (ADCC) and may also affect immunogenicity, by reducing the internalisation of the drug-receptor complex in antigen-presenting cells. It has also been demonstrated that the infliximab originator has at least two B cell epitopes in the Fc with a glycosylated pattern [32], and this may give it a different immunogenic profile from that of its biosimilar compound. Finally, although current randomised controlled trials and spontaneous reports have indicated comparable immunogenicity profiles between biosimilar and reference infliximab [33-38], these have all been based on the production of ADAs, which may depend on different immunogenic properties and biological pathways.

One of the main limitations of this study was that none of the biologically-treated patients (enrolled prior of the commercialization of biosimilar drugs) received a treatment with biosimilar infliximab, being all treated with Remicade ${ }^{\circledR}$. Consequently, data on the association between the efficacy/safety profile of Remsima ${ }^{\circledR}$ in vivo and Th9 cell percentages in vitro were not available. Moreover, differences in methotrexate and steroid intakes between the two groups (infliximab responders and non-responders) may have affected Th9 cell responses in vitro, despite no influence on Th9 cell percentages at baseline being reported and a lack of current scientific evidence.

\section{Materials and Methods}

\subsection{Population}

The study involved 55 outpatients with RA, diagnosed according to the ACR/EULAR 2010 criteria [39] who had participated in a previous study designed to explore the Th1/Th17-driven immunogenicity of infliximab (Remicade ${ }^{\circledR}$ ) [13]: Fifteen subjects free of immunosuppressive drugs, 20 patients successfully treated with branded infliximab, and 20 patients who had switched or swapped from branded infliximab to other biological drugs because of adverse events or inefficacy.

The patients and a matched control group of 10 healthy subjects were consecutively enrolled between June 2013 and December 2013.

The exclusion criteria were concurrent infections, atopic dermatitis, hematological disorders, concomitant or recent treatment with leflunomide or cyclosporine, or vaccinations in the previous two months, because these drugs or medical conditions can variously affect the Th cell pool [40-44].

The protocol was approved by the local Ethics Committee of the University Hospital Luigi Sacco, Milan, on 27 June 2013, registered with the number 364/2013 38AP (Resolution No. 484), and conduced in accordance with the Declaration of Helsinki. Written informed consent was obtained from all participants. 


\subsection{Immunological Analyses}

Peripheral blood mononuclear cells (PBMCs) were isolated from $18 \mathrm{~mL}$ blood samples collected into EDTA-containing Vacutainer tubes (Becton Dickinson, Rutherford, NJ, USA) by means of centrifugation on lymphocyte separation medium (Cedarlane Laboratories, Burlington, NC, USA), and their number and viability were determined using an ADAM-MC automatic cell counter (Digital-Bio, NanoEnTek Inc., Seoul, South Korea). The cells were cultured in RPMI 1640 plus penicillin, streptomycin, L-glutamine and 10\% pooled human AB serum (all from Euroclone, Siziano, Italy) at a concentration of $1 \times 106 / \mathrm{mL}$, and were incubated for $18 \mathrm{~h}$ with culture medium alone, branded infliximab $50 \mu \mathrm{g} / \mathrm{mL}$ (Remicade ${ }^{\circledR}$, Janssen Biologics, Leiden, The Netherlands), or its biosimilar (Remsima ${ }^{\circledR}$, Celltrion Healthcare, Budapest, Hungary); pokeweed mitogen (PWM) $(1 \mu \mathrm{g} / \mathrm{mL}$ of lectin from Phytolacca Americana, Sigma-Aldrich, Saint Louis, MO, USA) was used as a positive control to evaluate the cells' responsiveness [13]. The infliximab concentration of $50 \mu \mathrm{g} / \mathrm{mL}$ was chosen after titration testing -increasing drug concentrations and measuring median serum infliximab concentrations one hour after infusion (peak serum concentration: 39.9-219.1 $\mu \mathrm{g}$ ) [45]. In order to facilitate co-stimulation, $1 \mu \mathrm{g} / \mathrm{mL}$ of anti-human CD28 (R\&D Systems, Minneapolis, MN, USA) was added to the cell cultures. Brefeldin A $10 \mu \mathrm{g} / \mathrm{mL}$ (Sigma-Aldrich) was added after the first three $\mathrm{h}$, in order to inhibit cytokine secretion.

The percentage of Th9 lymphocytes was determined by flow cytometric analysis. Th9 lymphocytes were identified as PU.1 and IRF4-expressing, IL-9-secreting CD4 ${ }^{+} \mathrm{T}$ cells, although the percentage of OX40-expressing, IL-9-secreting CD4 ${ }^{+} \mathrm{T}$ cells was also measured, as the co-stimulatory molecule may selectively drive Th differentiation toward a Th9 phenotype, while repressing both Treg and Th17 cell development [2]. IL-9 production by naïve $\mathrm{CD}^{+} \mathrm{T}$ lymphocytes $\left(\mathrm{CCR} 7^{+}, \mathrm{CD}^{2} 5 \mathrm{RA}{ }^{+}\right)$, central memory $\mathrm{CD}^{+} \mathrm{T}^{-}$lymphocytes $\left(\mathrm{CCR}^{+}, \mathrm{CD}^{2} \mathrm{RA}^{-}\right)$, effector memory $\mathrm{CD}^{+}{ }^{+} \mathrm{T}$ lymphocytes $\left(\mathrm{CCR} 7^{-}, \mathrm{CD}^{2} 5 \mathrm{RA}^{-}\right)$, and terminally differentiated effector memory (TEMRA) $\mathrm{CD}^{+} \mathrm{T}$ lymphocytes (CCR7 ${ }^{-}, \mathrm{CD}^{2} 5 \mathrm{RA}^{+}$) was also evaluated.

The following human monoclonal antibodies (mAbs) were used: CD4 PE-Cy7, CD45RA FITC (Beckman Coulter, Milan, Italy); IRF4 PerCP-eFluor ${ }^{\circledR}$ and CD134 (OX40) FITC (eBioscience, Diego, CA, USA); IL-9 allophycocyanin (APC), CCR7 R-phycoerythrin (PE) and PU.1 PE (R\&D Systems). To evaluate the percentage of IL-9-secreting PU.1- and IRF4-expressing CD4 ${ }^{+} \mathrm{T}$ lymphocytes, the PBMCs were incubated with the $\mathrm{mAbs}$ for detecting cell surface antigens for $15 \mathrm{~min}$, permeabilised with fixation/permeabilisation buffer (eBiosciences) for $30 \mathrm{~min}$ at $4{ }^{\circ} \mathrm{C}$, and then stained with the antibodies for detecting intracellular transcription factors and IL-9 for a further 30 min at $4{ }^{\circ} \mathrm{C}$. To evaluate IL-9 production by naïve and memory CD4 ${ }^{+} \mathrm{T}$ cells, the PBMCs were incubated with the mAbs for detecting cell surface antigens for $15 \mathrm{~min}$ at room temperature (RT), fixed with $1 \%$ paraformaldehyde (PFA) for $15 \mathrm{~min}$ at $4{ }^{\circ} \mathrm{C}$, permeabilised with saponin (Sigma-Aldrich), and stained with the antibodies for detecting intracellular cytokines. Following $45 \mathrm{~min}$ of incubation in ice, the cells were fixed with $1 \%$ PFA.

The lymphocyte population was gated on the basis of its forward and side scatter properties, and further gated for CD4, CCR7 and CD45RA expression; at least 20,000 events were acquired within the CD4 gate. The samples were acquired using a Gallios flow cytometer, and the data were analysed using Kaluza software (both Beckman Coulter).

\subsection{Statistical Analysis}

The data were analysed parametrically, as they were normally distributed. The groups were compared using an unpaired Student's $t$ test for unequal variances, with a two-tailed $p$ value and Pearson's Chi squared test. A multivariate analysis was used to detect whether the subjects' demographic characteristics or therapeutic regimens affected the Th9 percentages. A $p$ value of $<0.05$ was considered statistically significant. The analyses were made using GraphPad Prism Software (GraphPad Software, San Diego, CA, USA) and SPSS, version 24.0 (International Business Machines Corporation, New York, NY, USA). 


\section{Conclusions}

In conclusion, the prevalence of Th9 cells is higher in RA patients than in healthy subjects, and may be restored by concomitant conventional and biological treatments. Based on our findings, PU. $1^{+}$, IRF4 ${ }^{+}$Th9 cells may be involved in orchestrating immune responses against epitopes of branded infliximab in patients failing the treatment; and this may be due to the recall and stimulation of both central and effector memory cells. On the other hand, despite a comparable profile in terms of immunogenicity emerged from other studies, biosimilar infliximab does not seem to activate these cell pools.

This study provides new insights into the immunogenicity of anti-TNF agents, which is routinely based on the detection of ADAs. The paradoxical activation of Th9 cells following exposure to infliximab may contribute to underlying inflammation, and thus explain the progressive loss of efficacy.

Nevertheless, the discrepancy between the Th9-driven immunogenicity of branded and biosimilar infliximab observed in our experiments may be attributable to our methodology rather than the real presence of dissimilar epitopes, and therefore deserves further investigation.

Author Contributions: Rossella Talotta conceived and designed the experiments; Rossella Talotta, Maria Chiara Ditto and Alberto Batticciotto recruited the patients; Angela Berzi and Daria Trabattoni performed the experiments; Angela Berzi and Rossella Talotta analyzed the data and performed statistical analysis; Angela Berzi and Daria Trabattoni contributed to reagents, materials and analysis tools; Rossella Talotta wrote the paper; Fabiola Atzeni, Andrea Doria and Piercarlo Sarzi-Puttini critically reviewed the manuscript.

Conflicts of Interest: The authors declare no conflict of interest.

\section{References}

1. Kaplan, M.H.; Hufford, M.M.; Olson, M.R. The development and in vivo function of T helper 9 cells. Nat. Rev. Immunol. 2015, 15, 295-307. [CrossRef] [PubMed]

2. Xiao, X.; Balasubramanian, S.; Liu, W.; Chu, X.; Wang, H.; Taparowsky, E.J.; Fu, Y.X.; Choi, Y.; Walsh, M.C.; Li, X.C. OX40 signaling favors the induction of Th 9 cells and airway inflammation. Nat. Immunol. 2012, 13, 981-990. [CrossRef] [PubMed]

3. Zielinski, C.E.; Corti, D.; Mele, F.; Pinto, D.; Lanzavecchia, A.; Sallusto, F. Dissecting the human immunologic memory for pathogens. Immunol. Rev. 2011, 240, 40-51. [CrossRef] [PubMed]

4. Harari, A.; Vallelian, F.; Pantaleo, G. Phenotypic heterogeneity of antigen-specific CD4 T cells under different conditions of antigen persistence and antigen load. Eur. J. Immunol. 2004, 34, 3525-3533. [CrossRef] [PubMed]

5. Jahn, E.M.; Schneider, C.K. How to systematically evaluate immunogenicity of therapeutic proteins-Regulatory considerations. New Biotecnhnol. 2009, 25, 280-286. [CrossRef] [PubMed]

6. Spinelli, F.R.; Valesini, G. Immunogenicity of anti-tumor necrosis factor drugs in rheumatic diseases. Clin. Exp. Rheumatol. 2013, 31, 954-963. [PubMed]

7. Harding, F.A.; Stickler, M.M.; Razo, J.; DuBridge, R.B. The immunogenicity of humanised and fully human antibodies. Residual immunogenicity resides in the CDR regions. $m A b s$ 2010, 2, 256-265. [CrossRef] [PubMed]

8. Atzeni, F.; Talotta, R.; Salaffi, F.; Cassinotti, A.; Varisco, V.; Battellino, M.; Ardizzone, S.; Pace, F.; Sarzi-Puttini, P. Immunogenicity and autoimmunity during anti-TNF therapy. Autoimmun. Rev. 2013, 12, 703-708. [CrossRef] [PubMed]

9. Aikawa, N.E.; de Carvalho, J.F.; Silva, C.A.; Bonfà, E. Immunogenicity of anti-TNF- $\alpha$ agents in autoimmune diseases. Clinic Rev. Allerg. Immunol. 2010, 38, 82-89. [CrossRef] [PubMed]

10. Vultaggio, A.; Matucci, A.; Nencini, F.; Pratesi, S.; Parronchi, P.; Rossi, O.; Romagnani, S.; Maggi, E. Anti-infliximab IgE and non-IgE antibodies and induction of infusion-related severe anaphylactic reactions. Allergy 2010, 65, 657-661. [CrossRef] [PubMed] 
11. Baert, F.; Noman, M.; Vermeire, S.; Van Assche, G.; D’Haens, G.; Carbonez, A.; Rutgeerts, P. Influence of immunogenicity on the long-term efficacy of infliximab in Crohn's disease. N. Engl. J. Med. 2003, 348, 601-608. [CrossRef] [PubMed]

12. Vermeire, S.; Noman, M.; Van Assche, G.; Baert, F.; D’Haens, G.; Rutgeerts, P. Effectiveness of concomitant immunosuppressive therapy in suppressing the formation of antibodies to infliximab in Crohn's disease. Gut 2007, 56, 1226-1231. [CrossRef] [PubMed]

13. Talotta, R.; Berzi, A.; Atzeni, F.; Batticciotto, A.; Clerici, M.; Sarzi-Puttini, P.; Trabattoni, D. Paradoxical Expansion of Th1 and Th17 Lymphocytes in Rheumatoid Arthritis Following Infliximab Treatment: A Possible Explanation for a Lack of Clinical Response. J. Clin. Immunol. 2015, 35, 550-557. [CrossRef] [PubMed]

14. Torres, M.J.; Chaves, P.; Doña, I.; Blanca-López, N.; Canto, G.; Mayorga, C.; Blanca, M. T-cell involvement in delayed-type hypersensitivity reactions to infliximab. J. Allergy Clin. Immunol. 2011, 128, 1365-1367. [CrossRef] [PubMed]

15. Dardalhon, V.; Awasthi, A.; Kwon, H.; Galileos, G.; Gao, W.; Sobel, R.A.; Mitsdoerffer, M.; Strom, T.B.; Elyaman, W.; Ho, I.C.; et al. IL-4 inhibits TGF-beta-induced Foxp3 ${ }^{+} \mathrm{T}$ cells and, together with TGF- $\beta$, generates IL-9 IL-10 $^{+}$Foxp3 ${ }^{-}$effector T cells. Nat. Immunol. 2008, 9, 1347-1355. [CrossRef] [PubMed]

16. Schmitt, E.; Klein, M.; Bopp, T. Th9 cells, new players in adaptive immunity. Trends Immunol. 2014, 35, 61-68. [CrossRef] [PubMed]

17. Elyaman, W.; Bradshaw, E.M.; Uyttenhove, C.; Dardalhon, V.; Awasthi, A.; Imitola, J.; Bettelli, E.; Oukka, M.; van Snick, J.; Renauld, J.C.; et al. IL-9 induces differentiation of TH17 cells and enhances function of FoxP3 ${ }^{+}$ natural regulatory T cells. Proc. Natl. Acad. Sci. USA. 2009, 106, 12885-12890. [CrossRef] [PubMed]

18. Leng, R.X.; Pan, H.F.; Ye, D.Q.; Xu, Y. Potential role of IL-9 in the pathogenesis of systemic lupus erythematosus. Am. J. Clin. Exp. Immunol. 2012, 1, 28-32. [PubMed]

19. Nalleweg, N.; Chiriac, M.T.; Podstawa, E.; Lehmann, C.; Rau, T.T.; Atreya, R.; Krauss, E.; Hundorfean, G.; Fichtner-Feigl, S.; Hartmann, A.; et al. IL-9 and its receptor are predominantly involved in the pathogenesis of UC. Gut 2015, 64, 743-755. [CrossRef] [PubMed]

20. Yanaba, K.; Yoshizaki, A.; Asano, Y.; Kadono, T.; Sato, S. Serum interleukin-9 levels are increased in patients with systemic sclerosis: Association with lower frequency and severity of pulmonary fibrosis. J. Rheumatol. 2011, 38, 2193-2197. [CrossRef] [PubMed]

21. Khan, I.H.; Krishnan, V.V.; Ziman, M.; Janatpour, K.; Wun, T.; Luciw, P.A.; Tuscano, J. Comparison of multiplex suspension array large-panel kits for profiling cytokines and chemokines in rheumatoid arthritis patients. Clin. Cytometry 2009, 76, 159-168. [CrossRef] [PubMed]

22. Hughes-Austin, J.M.; Deane, K.D.; Derber, L.A.; Kolfenbach, J.R.; Zerbe, G.O.; Sokolove, J.; Lahey, L.J.; Weisman, M.H.; Buckner, J.H.; Mikuls, T.R.; et al. Multiple cytokines and chemokines are associated with rheumatoid arthritis-related autoimmunity in first-degree relatives without rheumatoid arthritis: Studies of the Aetiology of Rheumatoid Arthritis (SERA). Ann. Rheum. Dis. 2013, 72, 901-907. [CrossRef] [PubMed]

23. Ciccia, F.; Guggino, G.; Rizzo, A.; Manzo, A.; Vitolo, B.; La Manna, M.P.; Giardina, G.; Sireci, G.; Dieli, F.; Montecucco, C.M.; et al. Potential involvement of IL-9 and Th9 cells in the pathogenesis of rheumatoid arthritis. Rheumatology (Oxford) 2015, 54, 2264-2272. [CrossRef] [PubMed]

24. Kundu-Raychaudhuri, S.; Abria, C.; Raychaudhuri, S.P. IL-9, a local growth factor for synovial T cells in inflammatory arthritis. Cytokine 2016, 79, 45-51. [CrossRef] [PubMed]

25. Talotta, R.; Berzi, A.; Atzeni, F.; Dell'Acqua, D.; Sarzi Puttini, P.; Trabattoni, D. Evaluation of Th9 lymphocytes in peripheral blood of rheumatoid arthritis patients and correlation with anti-tumor necrosis factor therapy: Results from an in vitro pivotal study. Reumatismo 2016, 68, 83-89. [CrossRef] [PubMed]

26. Zhu, J.; Paul, W.E. Heterogeneity and plasticity of T helper cells. Cell Res. 2010, 20, 4-12. [CrossRef] [PubMed]

27. Vultaggio, A.; Petroni, G.; Pratesi, S.; Nencini, F.; Cammelli, D.; Milla, M.; Prignano, F.; Annese, V.; Romagnani, S.; Maggi, E.; et al. ABIRISK Consortium. Circulating T cells to infliximab are detectable mainly in treated patients developing anti-drug antibodies and hypersensitivity reactions. Clin. Exp. Immunol. 2016, 186, 364-372. [CrossRef] [PubMed]

28. Remsima Assessment Report. EMA/CHMP/589317/2013. Available online: http://www.ema.europa.eu/ docs/en_GB/document_library/EPAR_-_Public_assessment_report/human/002576/WC500151486.pdf (accessed on 27 June 2013). 
29. Jung, S.K.; Lee, K.H.; Jeon, J.W.; Lee, J.W.; Kwon, B.O.; Kim, Y.J.; Bae, J.S.; Kim, D.I.; Lee, S.Y.; Chang, S.J. Physicochemical characterization of Remsima. mAbs 2014, 6, 1163-1177. [CrossRef] [PubMed]

30. Pierri, C.L.; Bossis, F.; Punzi, G.; De Grassi, A.; Cetrone, M.; Parisi, G.; Tricarico, D. Molecular modeling of antibodies for the treatment of TNF $\alpha$-related immunological diseases. Pharmacol. Res. Perspect. 2016, 4, e00197. [CrossRef] [PubMed]

31. Yamane-Ohnuki, N.; Satoh, M. Production of therapeutic antibodies with controlled fucosylation. $m A b s$ 2009, 1, 230-236. [CrossRef] [PubMed]

32. Homann, A.; Röckendorf, N.; Kromminga, A.; Frey, A.; Jappe, U. B cell epitopes on infliximab identified by oligopeptide microarray with unprocessed patient sera. J. Transl. Med. 2015, 13, 339. [CrossRef] [PubMed]

33. Yoo, D.H.; Hrycaj, P.; Miranda, P.; Ramiterre, E.; Piotrowski, M.; Shevchuk, S.; Kovalenko, V.; Prodanovic, N.; Abello-Banfi, M.; Gutierrez-Ureña, S.; et al. A randomised, double-blind, parallel-group study to demonstrate equivalence in efficacy and safety of CT-P13 compared with innovator infliximab when coadministered with methotrexate in patients with active rheumatoid arthritis: The PLANETRA study. Ann Rheum. Dis. 2013, 72, 1613-1620. [CrossRef] [PubMed]

34. Park, W.; Hrycaj, P.; Jeka, S.; Kovalenko, V.; Lysenko, G.; Miranda, P.; Mikazane, H.; Gutierrez-Ureña, S.; Lim, M.; Lee, Y.A.; et al. A randomised, double-blind, multicentre, parallel-group, prospective study comparing the pharmacokinetics, safety, and efficacy of CT-P13 and innovator infliximab in patients with ankylosing spondylitis: The PLANETAS study. Ann Rheum. Dis. 2013, 72, 1605-1612. [CrossRef] [PubMed]

35. Ben-Horin, S.; Yavzori, M.; Benhar, I.; Fudim, E.; Picard, O.; Ungar, B.; Lee, S.; Kim, S.; Eliakim, R.; Chowers, Y. Cross-immunogenicity: Antibodies to infliximab in Remicade-treated patients with IBD similarly recognise the biosimilar Remsima. Gut 2016, 65, 1132-1138. [CrossRef] [PubMed]

36. Smits, L.J.; Derikx, L.A.; de Jong, D.J.; Boshuizen, R.S.; van Esch, A.A.; Drenth, J.P.; Hoentjen, F. Clinical Outcomes Following a Switch from Remicade ${ }^{\circledR}$ to the Biosimilar CT-P13 in Inflammatory Bowel Disease Patients: A Prospective Observational Cohort Study. J. Crohns Colitis 2016, 10, 1287-1293. [CrossRef] [PubMed]

37. Buer, L.C.; Moum, B.A.; Cvancarova, M.; Warren, D.J.; Medhus, A.W.; Høivik, M.L. Switching from Remicade $^{\circledR}$ to Remsima ${ }^{\circledR}$ is safe and feasible: A prospective, open-label study. J. Crohns Colitis 2016, 11, 297-304.

38. Benucci, M.; Gobbi, F.L.; Bandinelli, F.; Damiani, A.; Infantino, M.; Grossi, V.; Manfredi, M.; Parisi, S.; Fusaro, E.; Batticciotto, A.; et al. Safety, efficacy and immunogenicity of switching from innovator to biosimilar infliximab in patients with spondyloarthritis: A 6-month real-life observational study. Immunol. Res. 2016, 65, 419-422. [CrossRef] [PubMed]

39. Aletaha, D.; Neogi, T.; Silman, A.J.; Funovits, J.; Felson, D.T.; Bingham, C.O., 3rd; Birnbaum, N.S.; Burmester, G.R.; Bykerk, V.P.; Cohen, M.D.; et al. 2010 Rheumatoid arthritis classification criteria: An American College of Rheumatology/European League Against Rheumatism collaborative initiative. Arthritis Rheum. 2010, 62, 2569-2581. [CrossRef] [PubMed]

40. García-Piñeres, A.; Hildesheim, A.; Dodd, L.; Kemp, T.J.; Williams, M.; Harro, C.; Lowy, D.R.; Schiller, J.T.; Pinto, L.A. Cytokine and chemokine profiles following vaccination with human papillomavirus type 16L1 virus-like particles. Clin. Vaccine Immunol. 2007, 14, 984-989. [CrossRef] [PubMed]

41. Purvis, S.; Asaad, R.; Valerio, I.; Sha, B.E.; Landay, A.L.; Lederman, M.M. Levels of proinflammatory cytokines in plasma after pneumoccoccal immunization in human immunodeficiency virus type 1-infected patients. Clin. Diagn. Lab. Immunol. 1999, 6, 427-428.

42. Weigmann, B.; Jarman, E.R.; Sudowe, S.; Bros, M.; Knop, J.; Reske-Kunz, A.B. Induction of regulatory T cells by leflunomide in a murine model of contact allergen sensitivity. J. Investig. Dermatol. 2006, 126, 1524-1533. [CrossRef] [PubMed]

43. Chong, A.S.; Ma, L.L.; Shen, J.; Blinder, L.; Yin, D.P.; Williams, J.W. Modification of humoral responses by the combination of leflunomide and cyclosporine in Lewis rats transplanted with hamster hearts. Transplantation 1997, 64, 1650-1657. [CrossRef] [PubMed] 
44. Belmar, N.A.; Lombardo, J.R.; Chao, D.T.; Li, O.; Ma, X.; Pong-Afar, M.; Law, D.A.; Starling, G.C. Dissociation of the efficacy and cytokine release mediated by an Fc-modified anti-CD3 mAb in a chronic experimental autoimmune encephalomyelitis model. J. Neuroimmunol. 2009, 212, 65-73. [CrossRef] [PubMed]

45. Clair, E.W.; Wagner, C.L.; Fasanmade, A.A.; Wang, B.; Schaible, T.; Kavanaugh, A.; Keystone, E.C. The relationship of serum infliximab concentrations to clinical improvement in rheumatoid arthritis: Results from ATTRACT, a multicenter, randomized, double-blind, placebo-controlled trial. Arthritis Rheum. 2002, 46, 1451-1459. [CrossRef] [PubMed]

2017 by the authors. Licensee MDPI, Basel, Switzerland. This article is an open access article distributed under the terms and conditions of the Creative Commons Attribution (CC BY) license (http:/ / creativecommons.org/licenses/by/4.0/). 